\title{
A Study on the Effect of Iron Deficiency Anaemia on Haemoglobin A1c Levels in Non-Diabetic Adults
}

\author{
Rahul Purbey¹, Bimal K. Agrawal², Prateek Kaushal³, Rakeshkumar Kela ${ }^{4}$ Ajith Thomas ${ }^{5}$
}

${ }^{1}$ Department of General Medicine, MM Institute of Medical Sciences and Research, Maharishi Markandeshwar Deemed to be University, Mullana, Haryana, India. ${ }^{2}$ Department of General Medicine, MM Institute of Medical Sciences and Research, Maharishi Markandeshwar Deemed to be University, Mullana, Haryana, India. ${ }^{3}$ Department of General Medicine, MM Institute of Medical Sciences and Research, Maharishi Markandeshwar Deemed to be University, Mullana, Haryana, India. ${ }^{4}$ Department of General Medicine, MM Institute of Medical Sciences and Research, Maharishi Markandeshwar Deemed to be University, Mullana, Haryana, India. ${ }^{5}$ Department of General Medicine, MM Institute of Medical Sciences and Research, Maharishi Markandeshwar Deemed to be University, Mullana, Haryana, India.

\section{ABSTRACT}

\section{BACKGROUND}

Iron deficiency anaemia is a common entity in India. Diabetic parameters may fluctuate with respect to the haemoglobin variants and nutritional anaemia. However, the exact association between them has not been fully elucidated. We aimed to estimate and compare the diabetic parameters and the levels of glycosylated haemoglobin (HbA1c) among anaemics and non-anaemics in nondiabetic patients.

\section{METHODS}

A comparative study was done in the Department of General Medicine, over a period of one-and-a-half years where 50 non-diabetic IDA patients as cases and 50 nondiabetic non-anaemic patients as controls were enrolled in the study. Iron profile and HbA1c levels were measured and compared at baseline. IDA patients were treated with iron supplements and the effects on the HbA1c levels after 3 months of treatment of iron deficiency were noted and analyzed. The data was entered in MS Excel spreadsheet and analysis was done using Statistical Package for Social Sciences (SPSS) version 21.0. A P value of $<0.05$ was considered to be statistically significant.

\section{RESULTS}

We found that anaemic patients had significantly higher fasting and random blood sugar levels with more patients in the pre-diabetic range as per HbA1c levels. The glycosylated $\mathrm{Hb}$ levels were significantly higher in Group A patients. $(\mathrm{p}<0.05)$. After initiating IDA treatment, there was a significant improvement in all the haematological parameters at 3 months follow up. There was a significant decrease in the HbA1c levels after three months of anaemia treatment. $(p<0.0001)$.

\section{CONCLUSIONS}

Iron deficiency anaemia has an inverse correlation with HbA1c levels. After correction of iron deficiency in the anaemic subjects, in most of the cases, the HbA1c levels declined to near normal values.

\section{KEY WORDS}

Anaemia, Glycosylated Haemoglobin, HbA1c, Iron Deficiency Anaemia
Corresponding Author:

Dr. Rahul Purbey,

Department of General Medicine,

MM Institute of Medical Sciences \&

Research, Mullana-133207, Ambala,

Haryana, India.

E-mail: rahulpurbey777@gmail.com

DOI: $10.14260 /$ jemds/2020/362

Financial or Other Competing Interests: None.

How to Cite This Article:

Purbey R, Agrawal BK, Kaushal P, et al. A study on the effect of iron deficiency anaemia on haemoglobin A1c levels in non-diabetic adults. J. Evolution Med. Dent. Sci. 2020;9(21):1649-1653, DOI: $10.14260 / \mathrm{jemds} / 2020 / 362$

Submission 20-03-2020,

Peer Review 05-05-2020,

Acceptance 11-05-2020,

Published 25-05-2020.

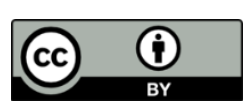




\section{BACKGROUND}

Worldwide, iron deficiency is the most prevalent anaemia. In India also, it is the most common form of anaemia. As India is the diabetes capital of the world, it is therefore imperative to assess the association present between iron deficiency anaemia (IDA) and Glycosylated haemoglobin (HbA1c). ${ }^{1}$ The association of $\mathrm{HbA1c}$ is not only restricted to IDA but may be seen with other nutritional deficiency anaemias such as folate deficiency, vitamin B12 deficiency, variant haemoglobins and haemolytic anaemias. ${ }^{1}$

Among the diabetic parameters, apart from the random sugar levels, HbA1c is an important marker for the glycaemic status as it is used as an indicator of a patient's glycaemic status over the preceding three months. The optimum level of HbA1c to be maintained in diabetics is $7 \%$ according to recent recommendations by the IDF and AACE. HbA1c levels are not affected by blood glucose alone. ${ }^{1}$ Initial studies done on the association of IDA with HbA1c levels by Brooks et $\mathrm{al}^{2}$ Mitchell et $\mathrm{al}^{3}{ }^{3}$ and Sluiter et $\mathrm{al}^{4}{ }^{4}$ revealed the existence of a relationship between them. However, Heyningen et al. ${ }^{5}$ and Hansen et al, 6 reported that there were no differences between the HbA1c levels of anaemic patients and controls.

The association may be due to the fact that glycosylated $\mathrm{Hb}$ is attached over the Red blood cell (RBC) surface and continues to remain there during the life cycle of the RBC which is around 3-4 months. The values of HbA1c thus denote the previously averaged glucose levels for 3-4 months. However, any nutritional deficiency or haemoglobin variant may alter the number, surface area, and size of the RBC, thereby affecting the attachment of glycosylated $\mathrm{Hb}$ and its values. $^{2-5}$ Determination of this association may be very helpful in monitoring of the diabetic status and the anaemic status simultaneously in the patients.

A person's HbA1c level is impacted by IDA which is a very common comorbidity found in the Indian population and correction of IDA can bring HbA1c levels back to normal. ${ }^{1} \mathrm{An}$ Indian study done by Sinha $\mathrm{N}$ et $\mathrm{al}^{7}{ }^{7}$ reported that IDA and HbA1c levels were directly proportional to each other, whereas Rai et al,8 found no differences. Thus, an additional advantage that can be gained from the determination of an association between IDA and HbA1c will be the regulation and monitoring of the treatment of anaemia and diabetes.

Previous studies have shown conflicting results regarding the exact relationship between IDA and HbA1c levels. Therefore, we performed the current study to investigate the effects of IDA on HbA1c levels among non-diabetic Indian patients. We also aimed to compare the levels between the cases and controls.

The determination of the values among the controls may help to screen the patients in the pre-diabetic range and advise them a cautious approach with lifestyle modifications to further prevent the progression to diabetes. It may also help to know if the treatment for anaemia alone can help in maintaining the HbA1c levels and control diabetes. This shall reduce a lot of financial burden of the medications and the daily use of insulin injections which may improve the quality of life of the patients.

\section{METHODS}

The prospective comparative study was conducted at the Department of General Medicine, from January 2018 to June 2019. Ethical clearance was obtained from the institutional ethical committee. The study comprised of patients in two groups: Group A: 50 non-diabetic anaemic patients. The sample size was based on the study of Nitin Sinha, et al ${ }^{7}$ who observed that HbA1c (\%) level in cases was $4.6 \pm 0.6$ as compared to $5.5 \pm 0.6$ in controls. Taking these values as reference, the minimum required sample size with $99 \%$ power of study and $1 \%$ level of significance is 22 patients in each study group. To reduce the margin of error, total sample size taken is 100 ( 50 patients per group).

The inclusion criteria were age $\geq 18$ years, peripheral blood smear showing microcytic hypochromic picture, and haemoglobin levels $<12 \mathrm{~g} / \mathrm{dL}$ in females and $<13 \mathrm{~g} / \mathrm{dL}$ in males as per WHO definition. ${ }^{9}$ Group B comprised of 50 nondiabetic non-anaemic patients. Those patients with diabetes mellitus (DM) as per ADA criteria 2016; haemolytic anaemia; known haemoglobinopathy; chronic kidney disease; liver disease; pregnancy; alcohol abuse; confirmed case of malignancy; hypothyroidism; h/o acute or chronic blood loss; and $\mathrm{h} / \mathrm{o}$ recent blood transfusion were excluded from the study. After selecting patients, written informed consent was obtained. Demographic data and detailed history regarding duration, symptoms, complications of any disease, treatment taken, co-morbidities and symptoms of iron deficiency were obtained. Clinical examination was done.

Details about history and examinations were recorded on a proforma. Following investigations were done: FBS, RBS, HbA1c, peripheral blood film, complete haemogram, MCV, $\mathrm{MCH}$ and $\mathrm{MCHC}$, serum ferritin, liver function tests, serum urea, serum creatinine, TSH if needed, and USG abdomen.

All patients with IDA were treated with oral iron supplementation in the form of $32.8 \mathrm{mg}$ elemental iron (160 mg ferric ammonium citrate) per day for 3 months and lab investigations were repeated after 3 months. In the controls, lab investigations were done only once at the time of enrolment.

\section{Statistical Analysis}

Quantitative variables were compared using Mann-Whitney Test between the two groups and Wilcoxon signed rank test was used to compare between baseline and post-treatment values. Qualitative variables were correlated using ChiSquare test/Fisher's exact test. $\mathrm{P}$ value of $<0.05$ was considered statistically significant. Data was entered in MS EXCEL spreadsheet and analysis was done using Statistical Package for Social Sciences (SPSS) version 21.0.

\section{RESULTS}

The mean age of the patients in groups A and B was $43.98 \pm$ 17.18 years and $45.02 \pm 16.84$ years, respectively. $(p>0.05)$ The number of females (58\% each) and males ( $42 \%$ each) in groups $\mathrm{A}$ and $\mathrm{B}$ were equal. The age distribution has been shown in Figure 1. 




Group A anaemic patients had significantly lower HB, MCV, MCH, MCHC, HCT and serum ferritin levels as compared to Group B non-anaemic adults $(\mathrm{p}<0.05)$ as shown in Table 1.

\begin{tabular}{|c|c|c|c|c|c|}
\hline \multirow{2}{*}{\multicolumn{2}{|c|}{ Parameters }} & \multicolumn{2}{|c|}{ Group } & \multirow{2}{*}{ Total } & \multirow{2}{*}{$\begin{array}{c}P \\
\text { Value }\end{array}$} \\
\hline & & $A(n=50)$ & $B(n=50)$ & & \\
\hline \multirow[b]{2}{*}{$\begin{array}{l}\text { Haemoglobin } \\
\text { (gm/dl) }\end{array}$} & \multirow{2}{*}{$\begin{array}{l}\text { Mean } \pm \text { S.D. } \\
\text { Median } \\
\text { (IQR) }\end{array}$} & $8.77 \pm 1.53$ & & & \multirow[b]{2}{*}{$<.0001$} \\
\hline & & $8.4(7.500-9.800)$ & $\begin{array}{r}13.4( \\
14 .\end{array}$ & & \\
\hline $\begin{array}{l}\text { Mean } \\
\text { corpuscular } \\
\text { volume(fl) }\end{array}$ & $\begin{array}{l}\text { Mean } \pm \text { S.D. } \\
\text { Median }\end{array}$ & $\begin{array}{r}67.5 \pm \\
66 \\
62 .\end{array}$ & $\begin{array}{l}89.3 \pm 4.52 \\
89 \\
(87-94)\end{array}$ & $\begin{array}{l}78.4 \pm 12.32 \\
80 \\
(66.500-89)\end{array}$ & $<.0001$ \\
\hline \multirow{2}{*}{$\begin{array}{c}\text { Mean } \\
\text { corpuscular } \\
\text { haemoglobin } \\
\text { (pg/cell) }\end{array}$} & Mear & & & & \multirow[b]{2}{*}{$-<.0001$} \\
\hline & & $22.5(21-24)$ & $29.5(28$ & $\begin{array}{r}26.5 \\
2\end{array}$ & \\
\hline \multirow{2}{*}{$\begin{array}{l}\text { Mean } \\
\text { corpuscular } \\
\text { haemoglobin } \\
\text { concentration } \\
\text { (gm/dl) }\end{array}$} & Mean \pm & $=1.55$ & 32.8 & 59 & \multirow{2}{*}{$<.0001$} \\
\hline & Med & $28.35(27-29.200)$ & $\begin{array}{r}32 . \\
33 .\end{array}$ & 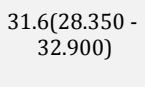 & \\
\hline \multirow{2}{*}{$\begin{array}{l}\text { Haematocrit } \\
(\%)\end{array}$} & Mea & 30. & 41 & & \multirow[b]{2}{*}{$<.0001$} \\
\hline & $\mathrm{Me}$ & 30. & 41 & & \\
\hline \multirow{2}{*}{$\begin{array}{l}\text { Serum } \\
\text { ferritin } \\
(\mathrm{ng} / \mathrm{ml})\end{array}$} & M & 10.5 & 59.3 & & \multirow[b]{2}{*}{$<.000$} \\
\hline & Media & $9(7-16)$ & $65(50-70)$ & $25.5(9-65)$ & \\
\hline \multicolumn{6}{|c|}{$\begin{array}{l}\text { able 1. Comparison of Haematological Parameters } \\
\text { amona the Studv Grouns }\end{array}$} \\
\hline
\end{tabular}

We found that anaemic patients had significantly higher fasting and random blood sugar levels with more patients in the pre-diabetic range as per HbA1c levels. The glycosylated $\mathrm{Hb}$ levels were significantly higher in Group A patients. $(\mathrm{p}<0.05)$ (table 2)

\begin{tabular}{|c|c|c|c|c|}
\hline & \multicolumn{2}{|c|}{ Group } & \multirow{2}{*}{ Total } & \multirow[b]{2}{*}{ P Value } \\
\hline & $A(n=50)$ & $B(n=50)$ & & \\
\hline \multicolumn{5}{|c|}{ FBS $(\mathrm{mg} / \mathrm{dl})$} \\
\hline Mean \pm S.D. & $107.72 \pm 11.06$ & $89.4 \pm 5.15$ & $103.96 \pm 11.85$ & \\
\hline Median (IQR) & $\begin{array}{c}110 \\
(100-116)\end{array}$ & $\begin{array}{c}89.5 \\
(85-92)\end{array}$ & $\begin{array}{c}101 \\
(96.500-114)\end{array}$ & $<.0001$ \\
\hline \multicolumn{5}{|c|}{ RBS (mg/dl) } \\
\hline Mean \pm S.D. & $113 \pm 16.84$ & $102.5 \pm 12.41$ & $107.75 \pm 15.63$ & \\
\hline Median (IQR) & $\begin{array}{c}112 \\
(101-127)\end{array}$ & $\begin{array}{c}100 \\
(92-114)\end{array}$ & $\begin{array}{c}110 \\
(97-118.500)\end{array}$ & 0.001 \\
\hline \multicolumn{5}{|c|}{ HbA1c $(\%)$} \\
\hline $\begin{array}{l}\text { HbA1c in pre-diabetic } \\
\text { range }(5.7-6.4 \%)\end{array}$ & $40(80.00 \%)$ & $0(0.00 \%)$ & $40(40.00 \%)$ & \multirow[t]{2}{*}{$<.0001$} \\
\hline Normal HbA1c $(<5.7 \%)$ & $10(20.00 \%)$ & $50(100.00 \%)$ & $60(60.00 \%)$ & \\
\hline Mean \pm S.D. & $5.92 \pm 0.37$ & $5.11 \pm 0.3$ & $5.52 \pm 0.53$ & \multirow[b]{2}{*}{$<.0001$} \\
\hline Median (IQR) & $\begin{array}{c}6 \\
(5.700-6.200) \\
\end{array}$ & $\begin{array}{c}5.1 \\
(4.800-5.300) \\
\end{array}$ & $\begin{array}{c}5.45 \\
(5.100-6) \\
\end{array}$ & \\
\hline Tab & n of Diabetic & ameters an & g the Stud & ups \\
\hline
\end{tabular}

After initiating IDA treatment, there was a significant improvement in all the haematological parameters at 3 months follow up. (Table 3)

\begin{tabular}{|c|c|c|c|c|}
\hline \multicolumn{2}{|c|}{ Parameters } & $\begin{array}{c}\text { Before } \\
\text { Treatment } \\
(n=50)\end{array}$ & $\begin{array}{c}\text { After } \\
\text { Treatment } \\
(n=50)\end{array}$ & $\begin{array}{c}P \\
\text { Value }\end{array}$ \\
\hline $\begin{array}{l}\text { Haemoglobin } \\
\text { (gm/dl) }\end{array}$ & $\begin{array}{c}\text { Mean } \pm \text { S.D. } \\
\text { Median (IQR) }\end{array}$ & $\begin{array}{c}8.77 \pm 1.53 \\
8.4(7.500-9.800)\end{array}$ & $\begin{array}{c}12.86 \pm 0.97 \\
12.7(12.300- \\
13.500)\end{array}$ & $<.0001$ \\
\hline $\begin{array}{l}\text { Mean corpuscular } \\
\text { volume(fl) }\end{array}$ & $\begin{array}{c}\text { Mean } \pm \text { S.D. } \\
\text { Median (IQR) }\end{array}$ & $\begin{array}{c}67.5 \pm 6.61 \\
66.5(62-74)\end{array}$ & $\begin{array}{c}81.44 \pm 5.06 \\
82(77-85)\end{array}$ & $<.0001$ \\
\hline $\begin{array}{l}\text { Mean corpuscular } \\
\text { haemoglobin } \\
\text { (pg/cell ) }\end{array}$ & $\begin{array}{c}\text { Mean } \pm \text { S.D. } \\
\text { Median (IQR) }\end{array}$ & $\begin{array}{c}22.5 \pm 2.08 \\
22.5(21-24)\end{array}$ & $\begin{array}{l}28.6 \pm 2.22 \\
28(27-31)\end{array}$ & $<.0001$ \\
\hline $\begin{array}{l}\text { Mean corpuscular } \\
\text { haemoglobin } \\
\text { concentration } \\
(\mathrm{gm} / \mathrm{dl})\end{array}$ & $\begin{array}{l}\text { Mean } \pm \text { S.D. } \\
\text { Median } \\
\text { (IQR) }\end{array}$ & $\begin{array}{c}28.32 \pm 1.55 \\
28.35 \\
(27-29.200)\end{array}$ & $\begin{array}{c}33.02 \pm 0.87 \\
33.2 \\
(32-33.800)\end{array}$ & $<.0001$ \\
\hline Haematocrit (\%) & $\begin{array}{l}\text { Mean } \pm \text { S.D. } \\
\text { Median (IQR) }\end{array}$ & $\begin{array}{c}30.5 \pm 2.08 \\
30.5(29-32)\end{array}$ & $\begin{array}{l}40.5 \pm 3.99 \\
41(38-43)\end{array}$ & $<.0001$ \\
\hline $\begin{array}{l}\text { Serum ferritin } \\
\text { (ng/ml) }\end{array}$ & $\begin{array}{l}\text { Mean } \pm \text { S.D. } \\
\text { Median (IQR) }\end{array}$ & $\begin{array}{c}10.91 \pm 5.51 \\
9(7-16)\end{array}$ & $\begin{array}{c}41.44 \pm 20.93 \\
40(22-57)\end{array}$ & $<.0001$ \\
\hline $\begin{array}{r}\text { Iron deficiency } \\
\text { Norm }\end{array}$ & anaemia & $\begin{array}{c}50(100.00 \%) \\
0(0.00 \%)\end{array}$ & $\begin{array}{c}0(0.00 \%) \\
50(100.00 \%)\end{array}$ & $<.0001$ \\
\hline
\end{tabular}

There was a significant decrease in the HbA1c levels after three months of anaemia treatment. Among the Group A anaemic patients, pre-diabetic range of patients significantly decreased from $80 \%$ to $30 \%(\mathrm{p}<0.0001)$. (Table 4$)$

\begin{tabular}{|cccc|}
\hline HbA1c (\%) & $\begin{array}{c}\text { Before Treatment } \\
(\mathbf{n = 5 0})\end{array}$ & $\begin{array}{c}\text { After Treatment } \\
(\mathbf{n = 5 0})\end{array}$ & $\begin{array}{c}\text { P } \\
\text { Value }\end{array}$ \\
HbA1c in pre-diabetic & $40(80.00 \%)$ & $15(30.00 \%)$ & \\
range (5.7- $-6.4 \%)$ & $10(20.00 \%)$ & $35(70.00 \%)$ & $<.0001$ \\
Normal HbA1c $(<5.7 \%)$ & $5.92 \pm 0.37$ & $5.49 \pm 0.42$ & $<.0001$ \\
Mean \pm S.D. & $6(5.700-6.200)$ & $5.5(5.200-5.700)$ & \\
Median (IQR) & \multicolumn{4}{|c}{ Table 4. Effect of IDA Treatment on HbA1c } & \\
\hline \multicolumn{4}{r}{}
\end{tabular}

\section{DISCUSSION}

Anaemia can have a significant impact on the regulation of the sugar levels and HbA1c levels of the body. The present study showed a significant association of anaemia and diabetic parameters; with significant improvement in the HbA1c levels after the treatment of IDA.

In present study, mean age of the patients in groups $A$ and $\mathrm{B}$ was $43.98 \pm 17.18$ years and $45.02 \pm 16.84$ years respectively; number of females (58\% each) and males (42\% each) in groups A and B were equal. In a study by Bharadwaj et al, ${ }^{1}$ the mean age of patients in study group was 30.3 years as compared to 36.24 years in controls; there were $66 \%$ females in study group and $40 \%$ in the controls group. Findings of all of these studies suggest that iron deficiency is commoner among females.

Age and gender were comparable among the 2 groups in our study. Other case control studies like Kalasker V et al,10 Aggarawal et $\mathrm{al}^{11}$ and Christy $\mathrm{A}$ et $\mathrm{al}^{12}$ showed similar results as our study.

In our study, 50 cases of non-diabetic IDA were compared against 50 normal non-diabetic patients. All cases had microcytic hypochromic anaemia which was similar to Bharadwaj et al, ${ }^{1}$ Aggarwal et al, ${ }^{11}$ and Christy A et al, ${ }^{12}$ who reported microcytic hypochromic anaemia to be present in all the patients with IDA.

In our study, Mean $\mathrm{Hb}, \mathrm{MCV}, \mathrm{MCH}, \mathrm{MCHC}, \mathrm{HCT}$, Ferritin were significantly lower in group A as compared to group B $(p<0.0001)$. Similar findings were seen in other studies also. 
Bharadwaj et al, ${ }^{1}$ and Aggarwal et al,11 also reported that variables like haemoglobin, haematocrit, $\mathrm{MCV}, \mathrm{MCH}, \mathrm{MCHC}$, serum ferritin were found to be comparatively lower in patients with IDA.

Serum ferritin is the first marker to decrease in IDA and its monitoring is important for early diagnosis and management. Only after a prolonged iron deficiency, other markers decrease, and smear changes appear like microcytosis and hypochromia. WHO has laid down the criteria for $\mathrm{Hb}<12 \mathrm{~g} / \mathrm{dL}$ and $<13 \mathrm{~g} / \mathrm{dL}$ to diagnose anaemia in females and males respectively and all cases in our study had anaemic $\mathrm{Hb}$ levels. Based on the other markers like serum ferritin, microcytosis and hypochromia on PBF, all IDA cases were labelled and monitored for treatment.

In our study, all diabetes associated biochemical markers like FBS and RBS were higher in patients with IDA. HbA1c, which analyses 3 months average sugar, was also significantly higher in group $\mathrm{A}$ as compared to group $\mathrm{B}$ (5.92\% vs $5.11 \%$; $\mathrm{P}<0.0001)$. According to the parameters, $80 \%$ of patients in group A were pre-diabetic at baseline as compared to all normal patients in group B. Even in other studies who determined HbA1c levels in IDA patients, corroborative results to our study were seen.

Coban et al (7.4\% vs. $5.9 \%),{ }^{13}$ Brooks et al (9.9\% vs. $7.9 \%),{ }^{2}$ Aggarwal et al (6.1\% vs $\left.4.1 \%\right),{ }^{11}$ Bharadwaj et al (6.6\% vs $5.48 \%),{ }^{1}$ and Kumar $\mathrm{M}$ et al, ${ }^{14}$ reported that mean HbA1c levels among IDA patients were significantly higher.

In contrast to our study, Kalasker $\mathrm{V}$ et al, ${ }^{10}$ and Sinha et $\mathrm{al}, 7$ reported that the mean $\mathrm{HbA1c}$ levels were significantly lower in anaemic patients than controls.

In our study, after IDA treatment, there was a significant increase in the mean $\mathrm{Hb}, \mathrm{MCV}, \mathrm{MCH}, \mathrm{MCHC}$, HCT and ferritin levels $(\mathrm{p}<0.0001)$ in all patients. The improvement in results in our study were comparable in line to other studies.

In a study by Bharadwaj et al, ${ }^{1}$ the mean haemoglobin in patients increased after 3 months of treatment but was still lower than the control values and this difference was still statistically significant $(\mathrm{p}<0.01)$. Similarly, there was increase in values of mean HCT, MCV, and MCH after 3 months of treatment when compared to baseline. Kumar et al, ${ }^{14}$ and Sinha et al,7 reported that mean values of $\mathrm{Hb}, \mathrm{MCV}, \mathrm{MCH}$, MCHC, HCT and ferritin increased after 3 months of treatment.

Among the diabetic parameters, HbA1c showed a significant decrease after IDA treatment (5.92\% to $5.49 \%$, $\mathrm{P}<0.0001)$; and the number of pre-diabetics reduced from $80 \%$ to $30 \%$. In comparison to our study, Bharadwaj et al, ${ }^{1}$ showed that after IDA treatment HbA1c decreased from $6.6 \%$ to $5.74 \%$. Kumar et al,14 reported that HbA1c showed improvement from $5.13 \%$ to $4.72 \%$ after IDA treatment. However, in the study by Sinha et $\mathrm{al}^{7}{ }^{7} \mathrm{HbA1c}$ changed from $4.6 \%$ to $5.9 \%$ after IDA treatment.

All the study results show that there is a significant association between improvement of IDA and reduction in average sugar levels (HbA1c). In a study conducted by Horton et $\mathrm{al}, 15$ it was demonstrated that $\mathrm{HbA} 1 \mathrm{c}$ is reduced because of the reason that the life span of the RBCs is decreased. In another study by Brooks et al, ${ }^{2}$ levels of HbA1c were higher in patients with IDA at baseline and reduced after treatment. The reason behind this given by them was that there is a change in the quaternary structure of haemoglobin and that there is glycation of beta globin chain which takes place more readily in the relative lack of iron.

A different reason was given by Sluiter et $\mathrm{al}^{4}{ }^{4}$ for explaining the results of study by Brooks et al. $^{2}$ They opined that the formation of glycated haemoglobin is an irreversible process. Therefore, HbA1c concentration in one erythrocyte will rise linearly with the age of the cell. Among patients who have normal values of blood glucose but having red cells younger than usual, following IDA treatment, there is reduction in concentration of HbA1c. Moreover, if the IDA is present for a long time, the rate of production of red cell decreases, which results in not only anaemia but also higher than normal average age of the circulating erythrocytes and, thus, increase in HbA1c levels.

El-Agouza et al, 16 explained it in terms of a balanced relationship between HbA1c and plasma glucose levels. So, a fall in haemoglobin concentration will lead to a rise in glycated fraction. Tarim et al, ${ }^{17}$ considered the reason for this to be the emergence of young erythrocytes in the circulation following iron therapy, which could have resulted in dilution and reducing the concentration of previously formed $\mathrm{HbA1c}$ and proposed that iron status of the patient must be keep in mind during the interpretation of HbA1c concentrations.

Rai et al,8 investigated different methods of estimating HbA1c; there was no difference found between colorimetry, ion-exchange chromatography, and affinity chromatography.

In studies by Mitchell et al,3 and Heyningen et al,5 no difference was observed between HbA1c (\%) values at baseline and following treatment in IDA patients. They reasoned that the differences found previously were not because of red cell age, but could be because of the different methods used for calculating HbA1c.

There is a straight forward correlation of IDA with levels of $\mathrm{HbA1c}$; the relationship between them is inverse. This means that as the haemoglobin level decreases with increase in severity of iron deficiency among anaemic patients, at the same time levels of $\mathrm{HbA1c}$ rise correspondingly. Furthermore, with correction of IDA in the anaemic individuals, the levels of HbA1c reduced to approximately normal values. It can be concluded that when $\mathrm{HbA} 1 \mathrm{c}$ is calculated for detecting past 3 months glycaemic status, there is an important role of factors other than glucose in its calculated value. These other factors should always be considered before ending up with a modification of therapeutic decision. In Indian settings, IDA is an extremely common condition and should always be ruled out when high levels of HbA1c are detected; for achieving true levels of $\mathrm{HbA1c}$, it should be corrected on priority basis. HbA1c levels should always be carefully interpreted considering all the factors that affect its value comprising some very common ones such as IDA, since India is the diabetic capital of the world and HbA1c is a very common investigation in day-today medical practice.

One of the limitations of our study is that it was a singlecenter hospital-based study, so its results cannot be generalized. Ours is a developing county, so its results cannot be implicated in the population of developed countries. Lack of long-term follow-up data further posed limitations in studying the relationship between IDA on HbA1c levels. 


\section{CONCLUSIONS}

At baseline, the diabetes associated biochemical markers such as FBS, RBS and HbA1c were higher in individuals with IDA as compared to individuals without IDA. There was a significant decrease in HbA1c among cases of IDA following IDA treatment and correction of iron deficiency. Thus, it can be concluded that HbA1c values may increase due to ongoing iron deficiency and both iron status and diabetic risk must be kept in mind while making diagnostic or therapeutic decisions for treating IDA and glycaemic states in any patient.

\section{REFERENCES}

[1] Bharadwaj K, Sharma SK, Rajpal N, et al. Effect of iron deficiency anaemia on haemoglobin A1c levels. Ann Clin Lab Res 2016;4:4.

[2] Brooks AP, Metcalfe J, Day JL, et al. Iron deficiency and glycosylated haemoglobin A. Lancet 1980;316(8186):141.

[3] Mitchell TR, Anderson D, Shepperd J. Iron deficiency, haemochromatosis and glycosylated haemoglobin. Lancet 1980;316(8197):747.

[4] Sluiter WJ, van Essen LH, Reitsma WD, et al. Glycosylated haemoglobin and iron deficiency. Lancet 1980;316(8193):531-2.

[5] Van Heyningen C, Dalton RG. Glycosylated haemoglobin in iron-deficiency anaemia. Lancet 1985;325(8433):874.

[6] Gram-Hansen P, Eriksen J, Mourits-Andersen T, et al. Glycosylated haemoglobin (HbA1c) in iron- and vitamin B12 deficiency. J Intern Med 1990;227(2):133-6.

[7] Sinha N, Mishra TK, Singh T, et al. Effect of iron deficiency anaemia on haemoglobin A1c levels. Ann Lab Med 2012;32(1):17-22.
[8] Rai KB, Pattabiraman TN. Glycosylated haemoglobin levels in iron deficiency anaemia. Indian J Med Res 1986;83:234-6.

[9] Shanthi B, Revathy C, Devi MAJ, et al. Effect of iron deficiency on glycation of haemoglobin in nondiabetics. J Clin Diagn Res 2013;7(1):15-7.

[10] Kalasker V, Sudhamadhur M, Kodliwadmath M, et al. Effect of iron deficiency anaemia on glycosylated haemoglobin levels in non-diabetic Indian adults. Int J Med Health Sci 2014;3(1):40-3.

[11] Aggarwal S, Kakkar R, Kaushik RM. Iron deficiency anaemia- does it affect the glycosylated haemoglobin levels in non- diabetic patients? J Adv Res Med 2014;1(3\&4):1-6.

[12] Christy AL, Manjrekar PA, Babu RP, et al. Influence of iron deficiency anaemia on haemoglobin A1C levels in diabetic individuals with controlled plasma glucose levels. Iran Biomed J 2014;18(2):88-93.

[13] Coban E, Ozdogan M, Timuragaoglu A. The effect of iron deficiency anaemia on the levels of haemoglobin A1c in nondiabetic patients. Acta Haematol 2004;112(3):126-8.

[14] Manojkumar CH, Nutakki G. A prospective study of effect of iron deficiency anaemia on HbA1c levels in nondiabetics. Int Arch Integ Med 2017;4(12):137-46.

[15] Horton BF, Huisman TH. Studies on the heterogeneity of haemoglobin. VII. Minor haemoglobin components in haematological diseases. Br J Haematol 1965;11(3):296304.

[16] El-Agouza I, Abu Shahla A, Sirdah M. The effect of iron deficiency anaemia on the levels of the haemoglobin subtypes: the possible consequences in a clinical diagnosis. Clin Lab Haematol 2002;24(5):285-9.

[17] Tarim 0, Küçükerdoğan A, Günay U, et al. Effects of iron deficiency anaemia on haemoglobin A1c in type 1 diabetes mellitus. Pediatr Int 1999;41(4):357-62. 